\title{
Killing effect of methionine enkephalin on melanoma in vivo and in vitro
}

\author{
DONG-MEI WANG ${ }^{1,2}$, XUE JIAO $^{3}$, NICOLAS P. PLOTNIKOFF $^{4}$, NOREEN GRIFFIN $^{4}$, \\ RUI-QUN QI ${ }^{5}$, XING-HUA GAO ${ }^{5}$ and FENG-PING SHAN ${ }^{1}$ \\ ${ }^{1}$ Department of Immunology, College of Basic Medical Science, China Medical University, Shenyang, Liaoning 110122; \\ ${ }^{2}$ College of Animal Husbandry and Veterinary, Jinzhou Medical University, Linghe, Jinzhou, Liaoning 121001; \\ ${ }^{3}$ Center for Translational Medicine, The Fourth Affiliated Hospital of China Medical University, \\ Shenyang, Liaoning 110032, P.R. China; ${ }^{4}$ Immune Therapeutics, Inc., Orlando, FL 32801, USA; \\ ${ }^{5}$ Department of Dermatology, No. 1 Hospital, China Medical University, Shenyang, Liaoning 110001, P.R. China
}

Received February 3, 2017; Accepted July 14, 2017

DOI: $10.3892 /$ or.2017.5918

\begin{abstract}
Melanoma is a common cutaneous malignancy, that is also found in specific mucosal sites, and is associated with a poor prognosis. The aim of the present study was to investigate the cytotoxicity of methionine enkephalin (MENK) for B16 melanoma cells in vivo and in vitro. The results of the present study allowed our conclusion that MENK regulates the proliferation of B16 cells, causing cell cycle arrest in the G0/G1 phase and a decrease in the percentage of cells in the $\mathrm{S}$ and $\mathrm{G} 2 / \mathrm{M}$ phases. Reverse transcription-quantitative polymerase chain reaction demonstrated that MENK increased opioid receptor expression in the B16 cells. Furthermore, the tumor volume and weight in the MENK-treated group were lower than those in the control group (NS) and MENK and naltrexone (NTX)-treated groups. MENK exerted both significant antitumor activity on the growth of B16 cells and a longer survival time in mice. The mice treated with MENK exhibited an increased ratio of $\mathrm{CD}^{+}$to $\mathrm{CD}^{+} \mathrm{T}$ cells as tested by flow cytometry (FCM), resulting in a ratio of 2.03 in the control group, 3.69 in the MENK-treated group, and 2.65 in the
\end{abstract}

Correspondence to: Professor Feng-Ping Shan, Department of Immunology, College of Basic Medical Science, China Medical University, 77 Puhe Road, Shenyang North New Area, Shenyang, Liaoning 110122, P.R. China

E-mail: fpshan@cmu.edu.cn

Professor Xing-Hua Gao, Department of Dermatology, No. 1 Hospital, China Medical University, 92 North Second Road, Heping, Shenyang, Liaoning 110001, P.R. China

E-mail: gaobarry@hotmail.com

Abbreviations: MENK, methionine enkephalin; MORs, $\mu$-opioid receptors; DORs, $\delta$-opioid receptors; KORs, $\kappa$-opioid receptors; RT-qPCR, reverse transcription quantitative polymerase chain reaction; MTS, 5-(3-carboxymethoxyphenyl)-2-(4,5-dimethylthiazoly)-3 -(4-sulfophenyl) tetrazolium

Key words: methionine enkephalin, melanoma, cell cycle, tumor immunity
MENK and NTX group. Furthermore, a significant increase in plasma levels of IL-2, IFN- $\gamma$ and TNF- $\alpha$ was revealed as assessed by ELISA. In conclusion, the results of the present study indicate that MENK has a cytotoxic effect on B16 melanoma cells in vitro and in vivo, and suggest a potential mechanism for these bioactivities. Therefore, we posit that MENK should be investigated, not only as a primary therapy for melanoma, but also as an adjuvant therapy in combination with chemotherapies.

\section{Introduction}

Human melanoma is one of the most aggressive cutaneous and mucosal cancers, and is characterized by different genetic alterations that are dependent upon body site and the extent of ultraviolet exposure (1). The incidence of cutaneous melanoma has been increasing rapidly, although, relatively few new chemotherapeutic agents have been approved. This contrasts with the use of checkpoint immune therapy for melanoma which has had a significant impact on melanoma outcomes. The treatment of in-transit and satellite melanoma metastases are challenging and the treatment options for these cutaneous and subcutaneous lesions, including surgical excision, radiotherapy, electro-chemotherapy and cryotherapy, have suboptimal response rates (2).

Methionine enkephalin (MENK), an inhibitory growth factor, binds to opioid growth factor receptor (OGFR) in a selective manner, upregulating cyclin-dependent inhibitory kinases, and thus potentially regulating tumor cell replication. MENK is produced in an autocrine or paracrine manner and is modulated by the cells themselves or the extracellular matrix $(3,4)$. MENK, known as an endogenous opioid peptide, was found to be an important inhibitor of human cancer cell proliferation $(5,6)$. There are $3 \mathrm{MENK}$ receptors that were identified more than 3 decades ago: specifically the $\mu-, \delta$ - and $\kappa$-opioid receptor (OR). The inhibitory effects of MENK on cell replication were first reported from the developing brains of rats $(7,8)$, then, in tissue culture studies using mouse and human neuroblastoma cell lines (9-12). MENK inhibits DNA synthesis and cell replication of normal cells and 
tissues $(13,14)$, human tumor cells $(15)$, and bacteria (16). The main function of MENK is to upregulate inhibitory kinases in the cell cycle process. The activity of MENK can be regulated by the potent and long-acting opioid receptor antagonist naltrexone (NTX), resulting in increased DNA synthesis and cell division.

At present, there is no published data examining the response of murine melanoma cell lines and tumors by MENK. We investigated the mechanism underlying the therapeutic effect of MENK on human melanoma, and confirmed that MENK can inhibit the progression, aggression and metastasis of melanoma cells. Based on our studies reported herein, we conclude that MENK provides a potential therapeutic strategy for the treatment of neoplasia and other immunosuppressive conditions, and we may further identify the cytotoxic activity and mechanisms of action of melanoma regulation, both in vivo and in vitro.

\section{Materials and methods}

Cell culture. B16 mouse melanoma cells were provided by No. 1 Hospital, China Medical University (Shenyang, China), and cultured in RPMI-1640 medium (Gibco; Thermo Fisher Scientific, Inc., Waltham, MA, USA), supplemented with $10 \%$ fetal calf serum (FCS; Biological Industries, Kibbutz Beit Haemek, Israel), $100 \mathrm{U} / \mathrm{ml}$ penicillin and $100 \mu \mathrm{g} / \mathrm{ml}$ streptomycin. Cells were cultured at $37^{\circ} \mathrm{C}$ in $5 \% \mathrm{CO}_{2}$, and cells in the exponential phase of growth were used for subsequent experiments.

Reagents. MENK ( $\geq 97 \%$ purity) was provided by Penta Biotech, Inc. (Union City, CA, USA). Reverse transcription-quantitative polymerase chain reaction (RT-qPCR) kits were purchased from Takara Bio, Inc. (Otsu, Japan). TRIzol ${ }^{\circledR}$ was obtained from Invitrogen; Thermo Fisher Scientific, Inc. Propidium iodide (PI), dimethyl sulfoxide and thymidine were purchased from Sigma-Aldrich; Merck Millipore (Darmstadt, Germany).

MENK co-culture with B16 cells. B16 cells were treated with various concentrations of $\operatorname{MENK}(0,2.5,5,10,12.5$ and $15 \mathrm{mg} / \mathrm{ml}$ in RPMI-1640) for various times (24, 48, 72 and $96 \mathrm{~h}$ ). Cell viability was evaluated by MTS assays and FCM.

Tumor model and MENK administration. Syngenic mice $(\mathrm{C} 57 \mathrm{Bl} / 6)$ at $6-8$ weeks of age were injected with B16 melanoma cells at a subcutaneous site. C57BL/6 mice (18-21 g) were obtained from Slac Laboratory Animals Co. Ltd. (Shanghai, China). All experiments with animals were conducted in pathogen-free conditions according to the guidelines of the NIH Guide for the Care and Use of Laboratory Animals. B16 cells $\left(2.0 \times 10^{6} / \mathrm{ml}\right)$ were subcutaneously injected into C57BL/6 mice $(0.2 \mathrm{ml} / \mathrm{mouse})$. Twenty-four hours after tumor cell injection, the mice were divided into 3 groups (10 mice/group). Mice in the MENK group were injected (i.p.) with MENK $(20 \mathrm{mg} / \mathrm{kg}$; $\geq 97$ purity; Penta Biotech, Inc.) once a day, consecutively for 30 days (17). Mice in the MENK and NTX groups were injected with NTX at $10 \mathrm{mg} / \mathrm{kg}$ by i.p. injection and $30 \mathrm{~min}$ later with MENK using the same schedule of administration. Mice in the vehicle control group received normal saline (NS) only. The mice were observed daily and when tumors became palpable, the shortest/longest diameters of the tumors were measured with a Vernier caliper every 3 days. Final tumor volume $\left(\mathrm{mm}^{3}\right)(\mathrm{V})$ was calculated via the following formula:

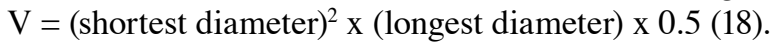

Cell growth and cell cycle analysis. MTS assay was carried out to determine the optimal concentration and incubation time for MENK. B16 cells were collected as target cells and seeded into 96 -well plates $\left(3 \times 10^{3} /\right.$ well). The B16 proliferation in each well was determined $3 \mathrm{~h}$ following plating by measuring the optical density at $570 \mathrm{~nm}$ using a bichromatic microplate reader.

The effect of MENK on B16 cell cycle was analyzed using FCM. B16 cells were seeded in 6-well plates for $48 \mathrm{~h}\left(5 \times 10^{5} /\right.$ well $)$. The cells were trypsinized, washed with phosphate-buffered saline (PBS), and fixed in 70\% ethanol. Prior to flow cytometric analysis, fixed cells were stained with $0.5 \mathrm{mg} / \mathrm{ml}$ PI in PBS containing $50 \mathrm{mg} / \mathrm{ml}$ RNase A. Cells were acquired on a flow cytometer and the data were analyzed using ModiFit LT $^{\mathrm{TM}}$ software version 4.0 (BD Biosciences, Franklin Lakes, NJ, USA).

$R T$ - $q P C R$ analysis of MENK-associated opioid receptors. The mRNA expression levels of $\mu \mathrm{OR}$ (MOR), $\delta \mathrm{OR}$ (DOR) and $\kappa \mathrm{OR}(\mathrm{KOR})$ were detected by RT-qPCR. B16 cells $\left(3 \times 10^{6} /\right.$ well) were divided into 3 groups: MENK (12.5 mg/ml), MENK+NTX $1 \mathrm{mg} / \mathrm{ml}$; and RPMI-1640 medium and cultured for $48 \mathrm{~h}$. Total RNA was extracted using TRIzol, and cDNA was synthesized using reverse transcriptase. Aliquots of cDNA were used as the template for $\mathrm{qPCR}$ reactions containing primers for MOR, DOR, KOR or $\beta$-actin. The primers were synthesized by Invitrogen; Thermo Fisher Scientific, Inc. and had the following oligonucleotide sequences: forward, 5'-TGCTCCTGGCTC AACTTGTCC-3' and reverse, 5'-GCGTGCTAGTGGCTAA GGCATCTG-3' for MOR; forward, 5'-CCATCCACATCT TCGTCATCGTCTG-3' and reverse, 5'-TCGTCCAGGAA GGCGTAGAGAAC-3' for DOR; forward, 5'-TCTCCCAGTG CTTGCCTTCTCC-3' and reverse, 5'-TTGCGGTCTTCATC TTCGTGTATCG-3' for KOR; and forward, 5'-TTCCAGCGT TCCTTCTTGGGTAT-3' and reverse, 5'-GTTGGCATAGAG GTGTTTACGG-3' for $\beta$-actin. The qPCR reactions were performed using an Applied Biosystems 7500 Real-Time PCR System (Thermo Fisher Scientific, Inc.) and SYBR ${ }^{\circledR}$ Premix Ex Taq II. The cycling conditions were as follows: an initial denaturation step at $95^{\circ} \mathrm{C}$ for $2 \mathrm{~min}$, followed by 40 cycles of denaturation at $95^{\circ} \mathrm{C}$ for $15 \mathrm{sec}$ and annealing at $60^{\circ} \mathrm{C}$ for $1 \mathrm{~min}$. Data were normalized to $\beta$-actin using the $2^{-\Delta \Delta \mathrm{Cq}}$ method (19).

Apoptosis analysis. The induction of apoptosis was analyzed by FCM. Apoptosis was assessed by labeling B16 cells with Annexin V-fluorescein isothiocyanate (FITC) and PI (BD Biosciences) according to the manufacturer's protocol. The samples were acquired on a FACSCalibur flow cytometer (BD Biosciences) and analyzed by ModiFit LT software version 4.0 or WinMDI version 2.9 (The Scripps Research Institute, La Jolla, CA, USA).

Transwell invasion assay. The invasive ability of cells was determined by Transwell assay. The $8-\mu \mathrm{m}$ pore polycarbonate filters were coated with extracellular matrix $(50 \mu \mathrm{g} / \mathrm{filter}$; 


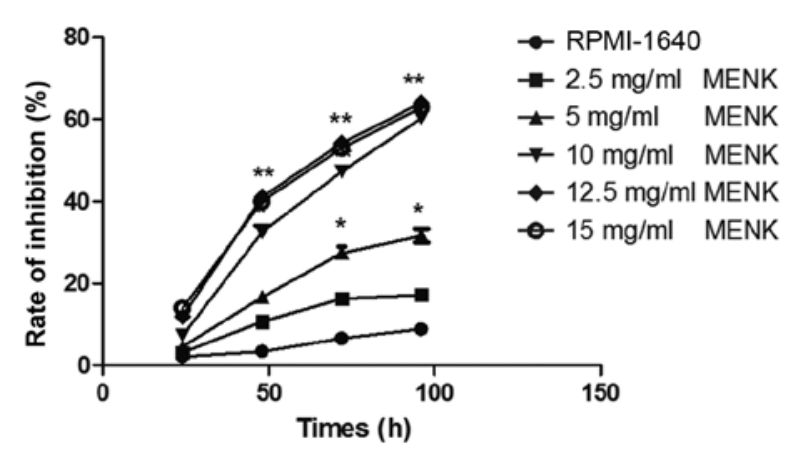

Figure 1. Growth inhibition of B16 cells by various concentrations of methionine enkephalin (MENK) after 24-96 h. The inhibitory rate of B16 cell growth following treatment with $0,2.5,5,10$ or $12.5 \mathrm{mg} / \mathrm{ml}$ MENK for 24, 48,72 and $96 \mathrm{~h}$ was evaluated by an MTS assay. The inhibition rate in the $12.5 \mathrm{mg} / \mathrm{ml}$ MENK group was significantly increased compared to control cultures that received RPMI-1640 only at $72 \mathrm{~h}(\mathrm{P}<0.01)$, and $96 \mathrm{~h}(\mathrm{P}<0.01$, ${ }^{*} \mathrm{P}<0.05$ and ${ }^{* *} \mathrm{P}<0.01$ vs. RPMI-1640).

Sigma-Aldrich; Merck Millipore); $500 \mu 1\left(2 \times 10^{5}\right)$ cells were added to the upper chamber and $500 \mu 1$ RPMI-1640 with $10 \%$ FCS was pipetted into the lower chamber. The non-invasive cells in the upper chamber were gently wiped-off $16 \mathrm{~h}$ later. The cells that penetrated to the lower chamber were stained with crystal violet, imaged and counted. Each experiment was performed in triplicate.

Tumor morphology. Tumor tissues from each mouse were fixed in $4 \%$ paraformaldehyde at $4{ }^{\circ} \mathrm{C}$ for histological assessment. After fixation, the tissues were dehydrated with a graded series of ethanol and embedded in paraffin. Thin sections (4- $\mu \mathrm{m})$ prepared from the paraffin-embedded tissues were mounted on glass slides, and deparaffinized with xylene. Then, tissues were mounted on glass slides and stained with H\&E for light microscopic examination. For morphological studies, 3 randomly selected sections were photographed using a x100 objective lens (Olympus BX-51) locating the tumor as described previously (21) (Olympus, Tokyo, Japan).

Analysis of macrophages and Th lymphocyte subsets by FCM. Splenocytes were separated and tested for membrane phenotypes CD4, CD8, CD3 and NK cells by FCM. Splenocytes were prepared as previously described. The digested and processed splenocytes were filtered by a 200 -micron nylon cell strainer (BD Biosciences) in PBS containing 2\% FCS to obtain single-cell suspensions and red blood cells were lysed. Isolated splenocytes were placed in $1 \mathrm{ml}$ of staining buffer at $1 \times 10^{6}$ cells $/ \mathrm{ml}$. The following antibodies were utilized: anti-CD3 (APC), anti-CD4 (PE), anti-CD8 (FITC) and anti-NK (PE).

Allcells were analyzed using FACSCalibur(BDBiosciences). The percentage of positive cell staining for each antibody was determined by comparing test samples with an isotype control. Data were analyzed by FCS Express Version 3 software.

ELISA assay for cytokines. The production of cytokines, IL-2, TNF- $\alpha$ and IFN- $\gamma$ in the sera obtained by retinal orbital bleed was measured using ELISA kits from eBioscience (San Diego, CA, USA).
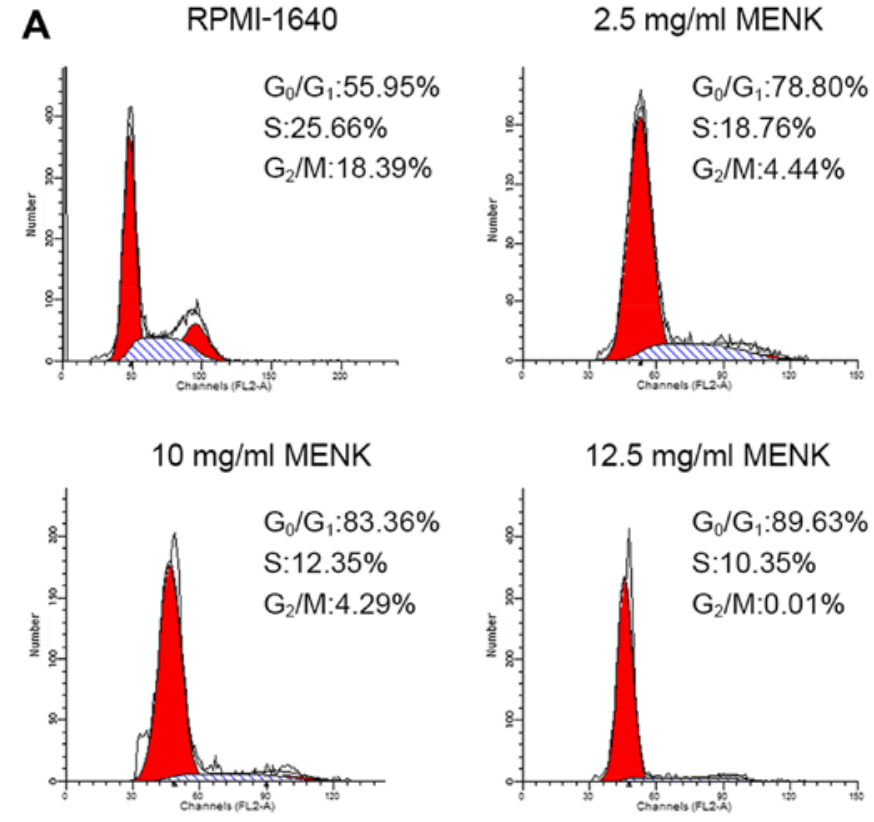

\section{B}

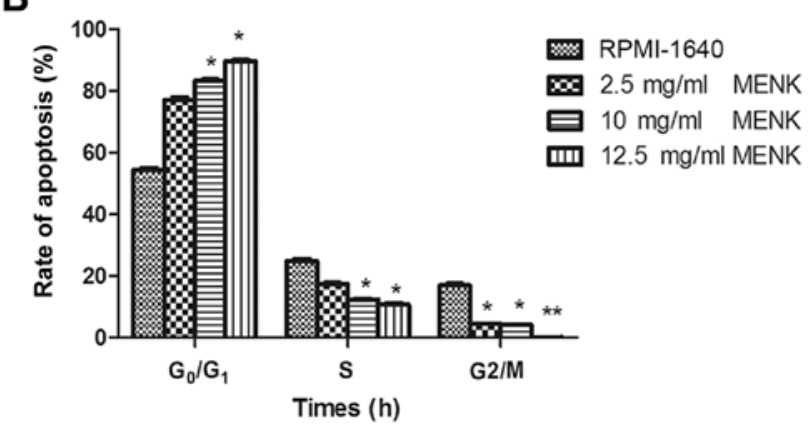

Figure 2. MENK inhibits B16 growth by cell cycle arrest. (A) The cell cycle of B16 cells treated with $0,2.5,10$ or $12.5 \mathrm{mg} / \mathrm{ml}$ MENK for $48 \mathrm{~h}$ was analyzed by flow cytometry. (B) The percentage of $10 \mathrm{mg} / \mathrm{ml}$ MENK-treated cells in the $\mathrm{G} 0 / \mathrm{G} 1$ phase was significantly elevated in comparison to the control $(\mathrm{P}<0.01)$. $\left(\mathrm{P}<0.01,{ }^{*} \mathrm{P}<0.05\right.$ and ${ }^{* *} \mathrm{P}<0.01$ vs. RPMI-1640). The mean percentage of cells in the $\mathrm{G} 0 / \mathrm{G} 1, \mathrm{~S}$ and $\mathrm{G} 2 / \mathrm{M}$ phases are shown.

Statistical analysis. All experiments were performed in triplicate at a minimum. Data are expressed as the mean \pm standard deviation. Statistical analyses were performed using SPSS software version 13.0 (SPSS, Inc., Chicago, IL, USA). Groups were compared using one-way analyses of variance followed by a post hoc test $\mathrm{S}-\mathrm{N}-\mathrm{K}$. $\mathrm{P}<0.05$ was considered to indicate a statistically significant difference.

\section{Results}

MENK inhibits B16 cell proliferation. The highest extent of B16 inhibition was observed at concentrations of MENK $>10 \mathrm{mg} / \mathrm{ml}$. As compared to the inhibition observed in the control group following $48 \mathrm{~h}$ of incubation, cell proliferation in the $12.5 \mathrm{mg} / \mathrm{ml}$ MENK-treated group was reduced by $41.06 \%$ $(\mathrm{P}<0.001$; Fig. 1). The viability of B16 cells treated with MENK was reduced in a dose- and time-dependent manner.

MENK induces cell cycle arrest. MENK reduced B16 cell proliferation and restricted them to the G0-G1 phase of 


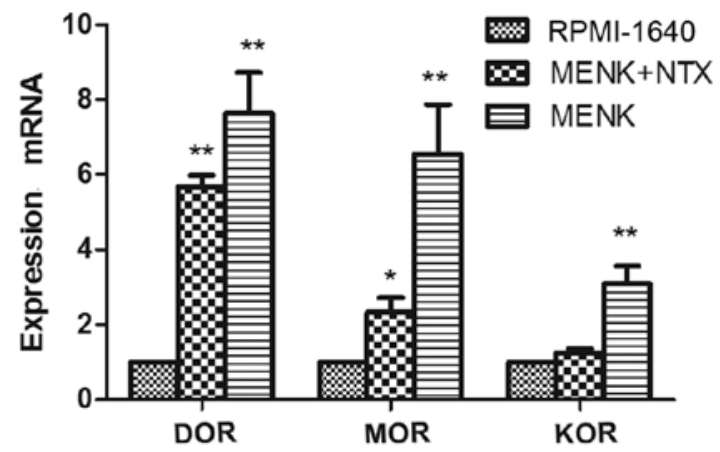

A

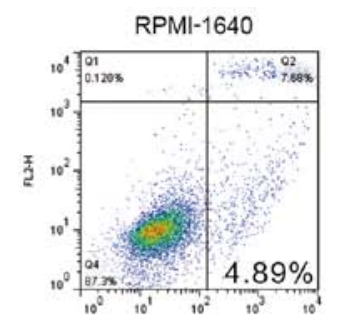

FL. T. H
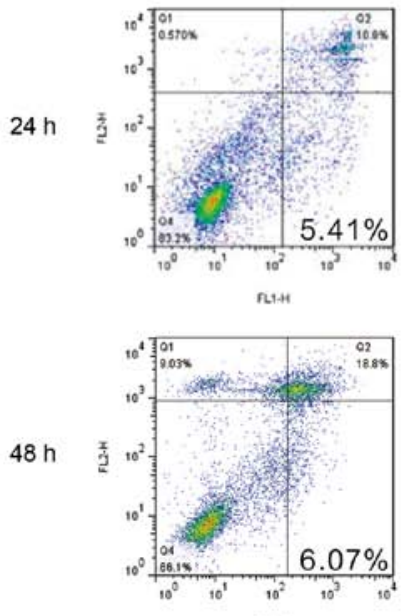

ค1.

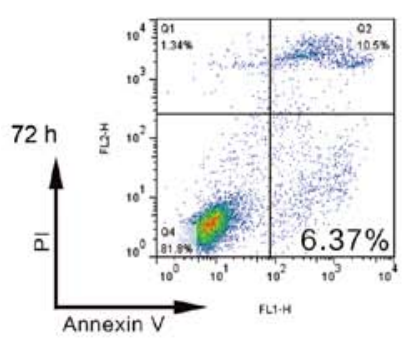

$2.5 \mathrm{mg} / \mathrm{ml}$ MENK

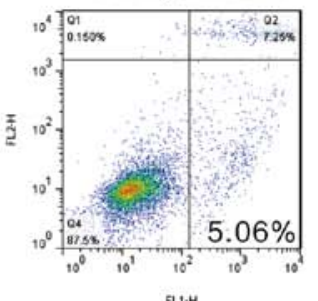

FL.
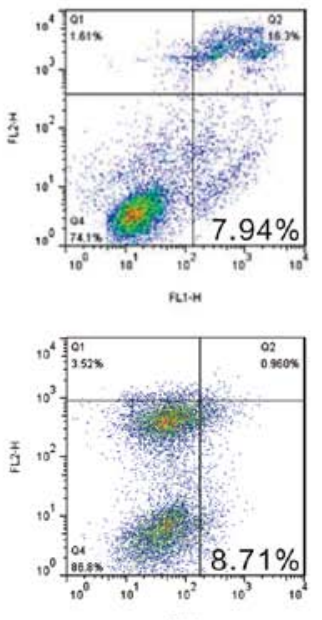

난

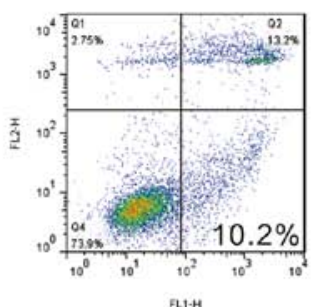

Figure 3. mRNA expression levels of DOR, MOR and KOR in B16 cells. mRNA expression levels were detected using reverse transcription-quantitative polymerase chain reaction following treatment with RPMI-1640 or the MENK and MENK+NTX groups in vitro for $48 \mathrm{~h}$. $\beta$-actin served as an internal reference. MENK upregulated the mRNA expression levels of DOR, MOR and KOR in B16 cells. DOR and MOR were significantly upregulated following MENK treatment compared with the RPMI-1640 group $(\mathrm{P}<0.01$, ${ }^{*} \mathrm{P}<0.05$ and ${ }^{* *} \mathrm{P}<0.01$ vs. RPMI-1640). The increased expression was attenuated by NTX. DOR, $\delta$-opioid receptor, MOR, $\mu$-opioid receptor; KOR, $\kappa$-opioid receptor; MENK, methionine enkephalin; NTX, naltrexone.

\section{B}

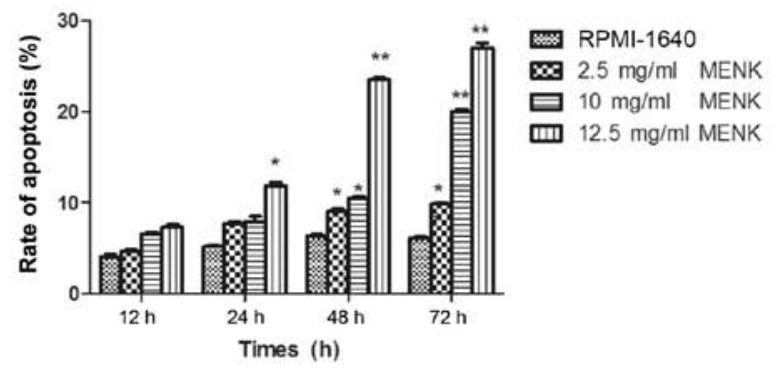

Figure 4. MENK induces apoptosis of the B16 cells. (A) Annexin V/PI staining of B16 cells was performed following treatment with $0,2.5,5,10$ or 12.5 mg/ml MENK for 12, 24, 48 or $72 \mathrm{~h}$. Apoptotic cells were defined as Annexin V+PI. Experiments were performed 3 times with similar results and one representative experiment is presented. (B) The rate of apoptosis increased from $4.22 \%$ in the control group to $25.1 \%$ in the $12.5 \mathrm{mg} / \mathrm{ml} \mathrm{MENK}$ treatment group ( $\mathrm{P}<0.01)$. $\left(\mathrm{P}<0.01,{ }^{*} \mathrm{P}<0.05\right.$ and ${ }^{* *} \mathrm{P}<0.01$ vs. RPMI-1640). MENK, methionine enkephalin; $\mathrm{PI}$, propidium iodide. 
Table I. Methionine enkephalin (MENK) inhibits B16 cell invasion.

\begin{tabular}{lcc}
\hline Group & Cell number & P-value \\
\hline Control & $95.65 \pm 6.71$ & \\
MENK $(\mathrm{mg} / \mathrm{ml})$ & & \\
2.5 & $90.43 \pm 7.28$ & 0.26 \\
5 & $81.35 \pm 5.35$ & $<0.001$ \\
10 & $78.67 \pm 5.83$ & $<0.001$ \\
12.5 & $65.83 \pm 4.21$ & \\
\hline
\end{tabular}

A Transwell assay was performed and the number of cells that had migrated to the lower chamber following a 12-h incubation was counted. Data are expressed as the mean \pm standard deviation $(n=6)$.

the cell cycle (Fig. 2A). The percentage of B16 cells in the G0/G1 phase cultured with $12.5 \mathrm{mg} / \mathrm{ml}$ MENK at $48 \mathrm{~h}$ was $89.63 \%$, as compared to $55.95 \%$ in control group $(\mathrm{P}=0.015$; Fig. 2B). Furthermore, the percentage of cells in the $S$ phase cultured with $12.5 \mathrm{mg} / \mathrm{ml}$ MENK was decreased to $10.35 \%$ compared to $25.66 \%$ of the control cells $(\mathrm{P}=0.004)$. The percentage of B16 cells in the $\mathrm{G} 2 / \mathrm{M}$ phase following treatment with $12.5 \mathrm{mg} / \mathrm{ml}$ MENK for $48 \mathrm{~h}$ was $0.01 \%$ compared with $18.39 \%$ in the control cells $(\mathrm{P}=0.24)$.

Culture of B16 cells with MENK increases mRNA opioid receptor expression. Following treatment with $12.5 \mathrm{mg} / \mathrm{ml}$ MENK, mRNA transcription of MOR, DOR and KOR by B16 cells was determined by RT-qPCR (Fig. 3). Their expression levels were upregulated post-treatment with MENK and the expression levels were blocked by NTX. Expression levels of DOR, MOR and KOR were 6.68-, 5.46- and 2.81-fold increased, compared to the control group. These differences reached statistical significance for DOR $(\mathrm{P}<0.001)$ and MOR $(\mathrm{P}=0.001)$. This increased expression of all 3 ORs was attenuated by NTX $(\mathrm{P}=0.004)$.

MENK induces apoptosis in vitro. Apoptosis of B16 cells was observed as assessed by Annexin V staining. Following MENK treatment of B16 cells, decreased viability was accompanied by alterations in cell morphology. This was confirmed by Annexin V/PI staining. There was a significant dose-dependent increase in Annexin $\mathrm{V}^{+} / \mathrm{PI}^{-}$apoptotic cells following MENK co-culture as compared to the control cells (Fig. 4A). Apoptosis appeared to peak at $48 \mathrm{~h}$ following addition of MENK to the culture. The apoptosis of B16 cells increased from $6.37 \%$ in the control group to $28.1 \%$ in the $12.5 \mathrm{mg} / \mathrm{ml}$ cultured MENK treatment group $(\mathrm{P}=0.001$; Fig. 4B).

MENK inhibits B16 cell invasion. The invasion capacity of B16 cells was determined using a Transwell assay. The number of cells that penetrated the membrane was significantly decreased $(5.46 \%)$ following culture with $5 \mathrm{mg} / \mathrm{ml}$ MENK $(\mathrm{P}=0.26)$ and by $31.18 \%$ following culture with $12.5 \mathrm{mg} / \mathrm{ml}$ MENK $(\mathrm{P}<0.001)$ as comparison to the control group (Table I).
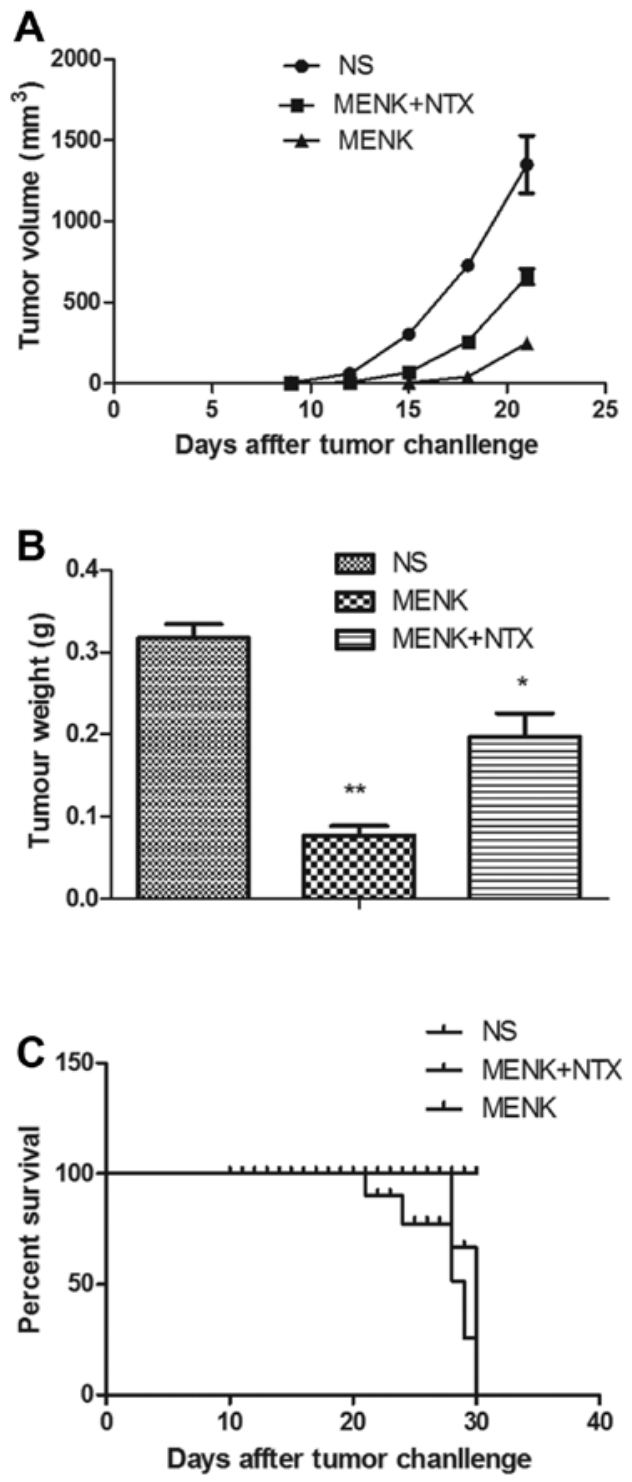

Figure 5. Control of tumor growth by MENK administration. (A) Tumor volume in the MENK-treated group compared with the control tumorbearing mice. (B) Effect of MENK on tumor weight in the tumor-bearing mice. (C) Survival rate in the experimental groups vs. the control tumorbearing mice; ${ }^{*} \mathrm{P}<0.05,{ }^{* *} \mathrm{P}<0.01$ vs. the NS (normal saline) group. MENK, methionine enkephalin.

Tumor size and survival. The tumor volume and weight in the MENK-treated group were significantly lower than those in the control and MENK+NTX groups. Mean tumor volume and weight were significantly different $(\mathrm{P}<0.01)$. MENK treatment significantly increased the survival time relative to the control group and this impact on survival was reversed by administration of NTX. The tumors in the MENK group were suppressed during the treatment. In contrast, the tumors in the vehicle control group grew quickly. The results determined that after 30 days, tumor size and weight were suppressed significantly in the MENK group (Fig. 5A and $\mathrm{B} ; \mathrm{P}<0.01$ ) in comparison to the control group. The survival rate in the MENK group was significantly prolonged in comparison with that in the control group $(\mathrm{P}<0.05)$, as shown in Fig. 5C. The results showed that MENK could delay tumor growth and significantly enhance the survival of mice bearing B16 tumors. 


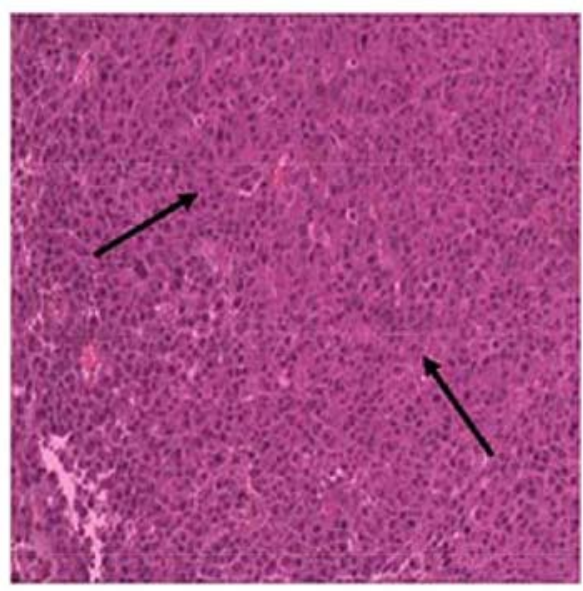

NS (x100)

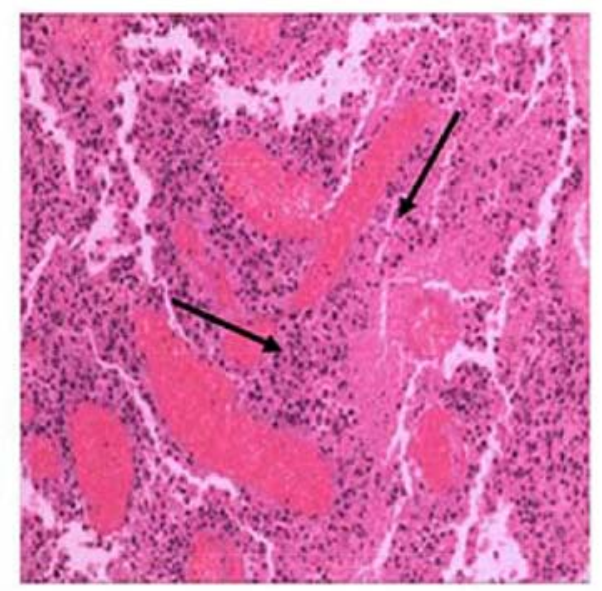

MENK (x100)

Figure 6. Morphology of histopathological tumor sections. Histopathology of tumors in the MENK-treated mice vs. that in the NS/control-treated mice (magnification, x100). The tumor regression was accompanied by apoptosis (black arrow) in the MENK-treated group. At the same time, tumors in the control group were observed as exhibiting diffused distribution in nests and vigorous growth. MENK, methionine enkephalin.
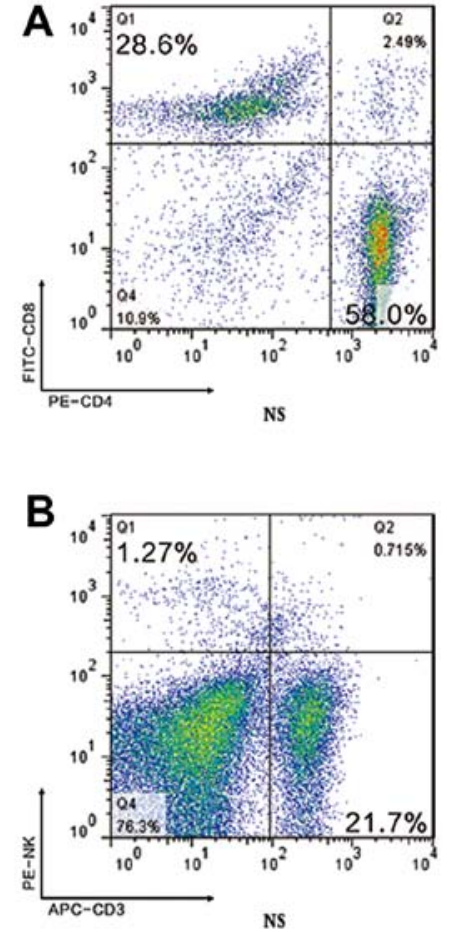
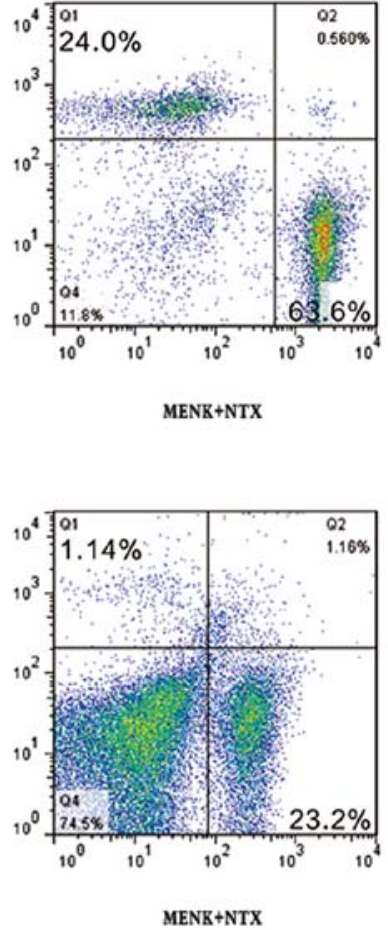
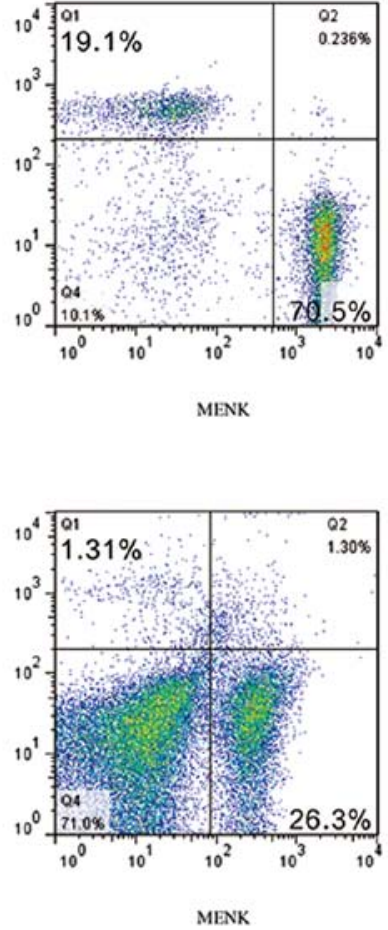

Figure 7. Phenotype characteristics of the splenocytes. FCM was undertaken following MENK administration daily for 30 days. (A) Ratio of CD4+ and CD8 ${ }^{+}$ $\mathrm{T}$ cells. (B) NK and $\mathrm{CD}^{+} \mathrm{T}$ cells. B cells were identified as those cells that are CD3 and NK-negative. MENK, methionine enkephalin.

Histopathologic morphology of tumors. Histopathologic analyses of control tumors, as previously reported, have shown that B16 tumor cells grow as diffused nests with a high frequency of mitotic cells, cellular heterogeneity, with an epithelioid or spindle type, cell volume and a large nuclear to cytoplasm ratio and varying nuclear morphology. A significant increase in the nucleoli:nucleoplasm ratio is observed, melanin is observed in the cytoplasm, less nuclear pyknosis is observed with occasional sites of scattered focal necrosis. The presence of necrosis in the MENK-treated tumors was increased. In the treated B16 tumors they were significantly reduced in size, had visible nuclear pyknosis, karyorrhexis, necrosis and a rich cytoplasm and an increase in inflammatory cell infiltration (Fig. 6).

Analysis of T lymphocyte subsets by FCM. The phenotypes of splenic T lymphocyte subsets were studied using 3-color FCM. The percentage of $\mathrm{CD}^{+}$lymphocytes in the MENK group was markedly higher than that in the control group, while the percentage of NK lymphocytes was not significantly increased. The mice treated with MENK exhibited an increased ratio of $\mathrm{CD} 4^{+}$to $\mathrm{CD} 8^{+} \mathrm{T}$ cells as assessed by FCM, with a ratio of 2.03 in the control group, 3.69 in the MENK-treated group and 2.65 

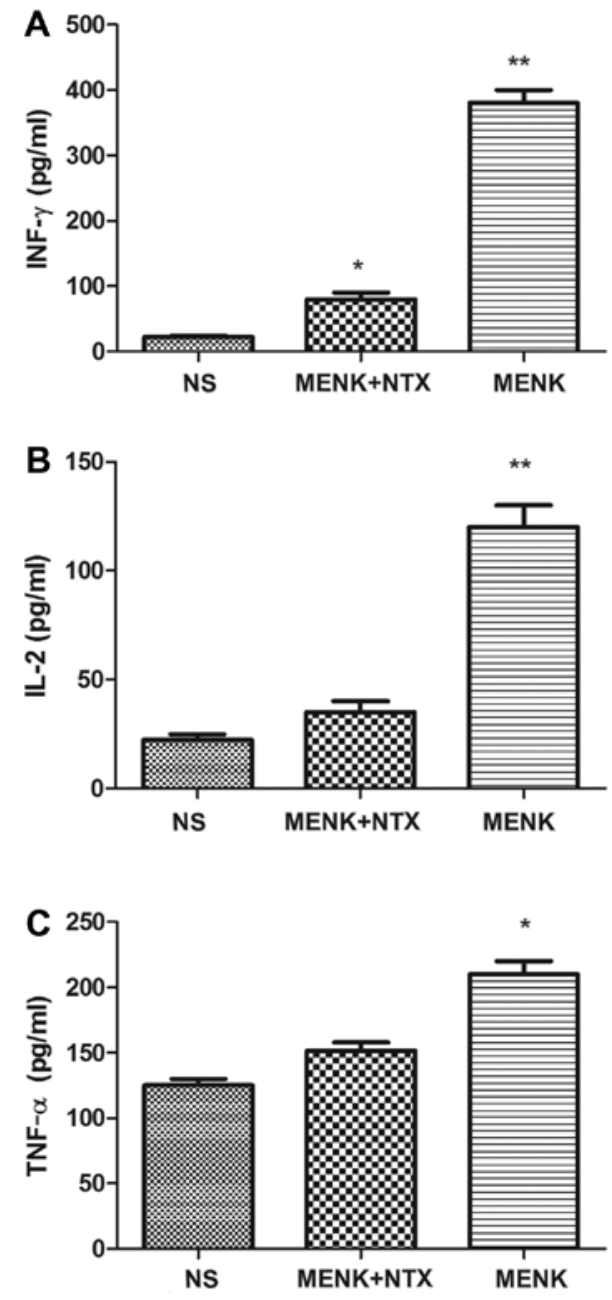

Figure 8. Levels of IL-2, IFN- $\gamma$ and TNF- $\alpha$ secreted from serum of the tumor-bearing mice injected with MENK. (A) IFN- $\gamma$. (B) IL-2. (C) TNF- $\alpha$; ${ }^{*} \mathrm{P}<0.05,{ }^{* * *} \mathrm{P}<0.01$, vs. the normal saline (NS)-treated group. MENK, methionine enkephalin.

in the MENK+NTX group. These data indicate that MENK induced Th1 immunity effectively in the tumor-bearing mice (Fig. 7).

Effect of MENK administration on serum cytokine levels. The cytokine levels in the serum of MENK-treated mice were assessed by ELISA analysis and included IL-2, IFN- $\gamma$ and TNF- $\alpha$ levels. Twenty-four hours after the last injection, serum was obtained from the retinal orbital plexus. In the MENK group all cytokines were significantly increased $(\mathrm{P}<0.01)$ compared with these levels in the NS and MENK+NTX groups (Fig. 8).

\section{Discussion}

Successful treatment of melanoma is a significant challenge, and novel combinations of targeted drugs and immunotherapies have recently provided encouraging outcomes, not only for melanoma, but also for other solid tumors. In recent years, cancer immunotherapy has become an important adjacent therapy to traditional cancer therapies. By regulation of the immune system, particularly immune cells within the tumor microenvironment, the growth of some cancers can be controlled (22).

The coordination of the endocrine and immune systems maintains the stability of many host functions. Indeed, MENK may contribute to immune responses by activating multiple types of immune cells for tumors and viral infections, enabling them to secrete various cytokines or killing target cells directly $(23,24)$. Opioid peptides and opioid receptors have been found in a variety of human cancer tissues and to have a direct influence on the growth of neural and non-neural cells and tissues (25). Moreover, there are interactions among immune cells which take place by the secretion of a variety of cytokines. In our previous study, we demonstrated that MENK alone or in combination with IL-2 or IFN- $\gamma$, respectively strengthened the pathway between dendritic cells (DCs) and $\mathrm{CD} 4^{+} \mathrm{T}$ cells, and induced maturation of DCs with higher production of IL-12 (26). MENK was found to inhibit the growth and induce apoptosis of A375 cells (27). In the present study, we made the unique discovery that MENK not only can inhibit the proliferation and metastasis of B16 cells directly, but also can indirectly kill B16 cells by stimulating lymphocyte subsets and cytokine secretion to achieve the therapeutic goal. The importance of this discovery cannot be emphasized sufficiently since it now provides a direct clue to the solution for melanoma B16 treatment with MENK.

The present study investigated the detailed mechanisms underlying the effects of MENK on melanoma B16 cell tumor-bearing mice. Our results conclude that: ii) the optimal concentration of MENK to inhibit the progression, aggression and metastasis of B16 cells was $12.5 \mathrm{mg} / \mathrm{ml}$. ii) The expression of DOR, MOR and KOR in B16 cells was upregulated post-treatment with MENK, and the increased expression was attenuated by NTX. iii) MENK retarded the growth of B16 cells, and restricted them to a G0-G1 portion of the cell cycle. iv) Apoptosis of B16 cells was observed. v) The result of the Transwell assay also concluded that $12.5 \mathrm{mg} / \mathrm{ml}$ MENK effectively inhibited B16 cell invasion. vi) Treatment of B16 primary tumors with MENK administration reduced tumor volume and weight and prolonged survival relative to control-treated mice and this therapeutic activity was blocked following the administration of NTX. This is consistent with prior studies of MENK-increased antitumor resistance in mice against the growth of B16 cells and also increased survival time. vi) The histopathologic morphology of tumors demonstrated significant differences between the MENK and NS groups (8). Furthermore, in our present study the mice treated with MENK exhibited increased frequency of $\mathrm{CD}^{+}$and $\mathrm{CD}^{+} \mathrm{T}$ cells and ratio as detected by FCM, with ratios of 2.03 in the control group, 3.69 in the MENKtreated group and 2.65 in the MENK+NTX group (Fig. 7). ix) MENK induced an increase in IL-2, IFN- $\gamma$ and TNF- $\alpha$ as assessed by ELISA. Therefore, MENK not only inhibited the proliferation of B16 cells directly, but also regulated B16 tumor growth by stimulating $\mathrm{T}$ cell frequency and cytokine secretion.

The immune system includes a complex, diverse network of leukocyte cells by forming a feedback loop regulated by secreted cytokines. The secretion of IFN- $\gamma$ may also entice B cells to produce opsonizing antibodies, which aids in phagocytosis by the macrophage and antibody-dependent, 
cell-mediated cytotoxicity of NK cells (28). TNF- $\alpha$ is a multi-functional cytokine, playing a pivotal role in cell apoptosis, cell proliferation and tumorigenesis. A high level of TNF- $\alpha$ could enhance the cytotoxic effect against cancer cells, direct blockage of cancer cells, ischemic necrosis of tumors and lysis of cancer cells (29). TNF- $\alpha$ also can induce inflammation of capillary endothelium resulting in tumor necrosis (30). In the present study, MENK promoted the secretion of IFN- $\gamma$, TNF- $\alpha$ and IL-2.

Intralesional IL-2 may be beneficial for the treatment of intransit melanoma metastases. Previous studies used lower concentrations ( 3 and 3.6 million units) with lower response rates (50 and $62.5 \%$ ) compared with the recent study by Shi et al (31), in which higher-dose IL-2 (up to 22 million units) combined with topical imiquimod and tretinoin $0.1 \%$ cream resulted in a $100 \%$ complete response (32).

In response to immune system, antigen-presenting cells such as DCs secrete a variety of cytokines by stimulating $\mathrm{CD}^{+}{ }^{+} \mathrm{T}$ cells to become differentiated into Th1, Th2 or Th17 by a process known as polarization (33). Th1 cells are often considered as pro-inflammatory factors, which could respond to IL-12, produce IFN- $\gamma$ and enhance the pathway of CD4 ${ }^{+}$ $\mathrm{T}$ cell proliferation and inflammation $(34,35)$. In the present study, the ratio of $\mathrm{CD}^{+}$to $\mathrm{CD}^{+} \mathrm{T}$ cells was increased. It is also helpful to gain deep insight into the immunological mechanisms of MENK for its positive immune regulation. Based on the above findings, we may consider this strategy for application in cancer therapy in the future.

From the results of the present study we conclude that MENK inhibits the growth and induces the apoptosis of B16 cells, resulting in a potential therapeutic mechanism. MENK administration also enhanced immune function in tumor-bearing mice and thus may act as an immunomodulator for patients with melanoma. Therefore, MENK should be investigated as an adjuvant therapy for melanoma patients in combination with chemotherapy. Additional studies are needed to obtain deeper insight into the immunological mechanisms of MENK and its immune regulatory activity. Further studies are still needed to develop an optimal strategy for the adjuvant use of MENK in the treatment of melanoma.

\section{Acknowledgements}

The present study was supported by the China Natural Science Foundation (31670921 to F.S.), and the Liaoning Major Science and Technology Platform for Institutions. The authors thank their colleagues who contributed to the present study.

\section{References}

1. Curtin JA, Fridlyand J, Kageshita T, Patel HN, Busam KJ, Kutzner H, Cho KH, Aiba S, Bröcker EB, LeBoit PE, et al: Distinct sets of genetic alterations in melanoma. N Engl J Med 353: 2135-2147, 2005.

2. Zagon IS, Sassani JW and McLaughlin PJ: Reepithelialization of the human cornea is regulated by endogenous opioids. Invest Ophthalmol Vis Sci 41: 73-81, 2000.

3. Zagon IS, Sassani JW, Wu Y and McLaughlin PJ: The autocrine derivation of the opioid growth factor, $\left[\mathrm{Met}^{5}\right]$-enkephalin, in ocular surface epithelium. Brain Res 792: 72-78, 1998.

4. Wolf IH, Richtig E, Kopera D and Kerl H: Locoregional cutaneous metastases of malignant melanoma and their management Dermatol Surg 30: 244-247, 2004
5. Zagon IS and McLaughlin PJ: Naltrexone modulates tumor response in mice with neuroblastoma. Science 221: 671-673, 1983.

6. Zagon IS and McLaughlin PJ: Opioid antagonists inhibit the growth of metastatic murine neuroblastoma. Cancer Lett 21: 89-94, 1983.

7. Zagon IS, Rhodes RE and McLaughlin PJ: Distribution of enkephalin immunoreactivity in germinative cells of developing rat cerebellum. Science 227: 1049-1051, 1985.

8. Zagon IS and McLaughlin PJ: Endogenous opioid systems regulate cell proliferation in the developing rat brain. Brain Res 412: 68-72, 1987.

9. Zagon IS and McLaughlin PJ: Endogenous opioid systems, stress, and cancer. In: Enkephalins-Endorphins: Stress and the Immune System. Plotnikoff NP, Murgo AJ, Faith RE and Good RA (eds). Plenum Press, New York, pp81-100, 1986.

10. Zagon IS, McLaughlin PJ, Goodman SR and Rhodes RE: Opioid receptors and endogenous opioids in diverse human and animal cancers. J Natl Cancer Inst 79: 1059-1065, 1987.

11. Zagon IS and McLaughlin P: Endogenous opioids and the growth regulation of a neural tumor. Life Sci 43: 1313-1318, 1988.

12. Zagon IS and McLaughlin PJ: Endogenous opioid systems regulate growth of neural tumor cells in culture. Brain Res 490: 14-25, 1989.

13. Hauser KF, McLaughlin PJ and Zagon IS: Endogenous opioids regulate dendritic growth and spine formation in developing rat brain. Brain Res 416: 157-161, 1987.

14. McLaughlin PJ and Zagon IS: Modulation of human neuroblastoma transplanted into nude mice by endogenous opioid systems. Life Sci 41: 1465-1472, 1987.

15. Zagon IS, Wu Y and McLaughlin PJ: Opioid growth factor inhibits DNA synthesis in mouse tongue epithelium in a circadian rhythm-dependent manner. Am J Physiol 267: R645-R652, 1994.

16. Zagon IS and McLaughlin PJ: An opioid growth factor regulates the replication of microorganisms. Life Sci 50: 1179-1187, 1992.

17. Shan F, Xia Y, Wang N, Meng J, Lu C, Meng Y and Plotnikoff NP: Functional modulation of the pathway between dendritic cells (DCs) and CD4 ${ }^{+} \mathrm{T}$ cells by the neuropeptide: Methionine enkephalin (MENK). Peptides 32: 929-937, 2011.

18. Quidville V, Segond N, Pidoux E, Cohen R, Jullienne A and Lausson S: Tumor growth inhibition by indomethacin in a mouse model of human medullary thyroid cancer: Implication of cyclooxygenases and 15-hydroxyprostaglandin dehydrogenase. Endocrinology 145: 2561-2571, 2004.

19. Livak KJ and Schmittgen TD: Analysis of relative gene expression data using real-time quantitative PCR and the $2^{-\Delta \Delta C_{\mathrm{T}}}$ method. Methods 25: 402-408, 2001.

20. El-Gazzar A, Perco P, Eckelhart E, Anees M, Sexl V, Mayer B, Liu Y, Mikulits W, Horvat R, Pangerl T, et al: Natural immunity enhances the activity of a DR5 agonistic antibody and carboplatin in the treatment of ovarian cancer. Mol Cancer Ther 9: 1007-1018, 2010

21. Wang Q, Gao X, Yuan Z, Wang Z, Meng Y, Cao Y, Plotnikoff NP, Griffin N, and Shan F: Methionine enkephalin (MENK) improves lymphocyte subpopulations in human peripheral blood of 50 cancer patients by inhibiting regulatory $\mathrm{T}$ cells (Tregs). Hum Vaccin Immunother 10: 1836-1840, 2014.

22. Li W, Chen W, Herberman RB, Plotnikoff NP, Youkilis G, Griffin N, Wang E, Lu C and Shan F: Immunotherapy of cancer via mediation of cytotoxic $\mathrm{T}$ lymphocytes by methionine enkephalin (MENK). Cancer Lett 344: 212-222, 2014.

23. Sassani JW, Mc Laughlin PJ and Zagon IS: The Yin and Yang of the Opioid Growth Regulatory System: Focus on Diabetes - The Lorenz E. Zimmerman Tribute Lecture. J Diabetes Res 2016: 9703729, 2016.

24. McLaughlin PJ, McHugh DP, Magister MJ and Zagon IS: Endogenous opioid inhibition of proliferation of $\mathrm{T}$ and $\mathrm{B}$ cell subpopulations in response to immunization for experimental autoimmune encephalomyelitis. BMC Immunol 16: 24, 2015.

25. Zagon IS, Donahue RN and McLaughlin PJ: Opioid growth factor-opioid growth factor receptor axis is a physiological determinant of cell proliferation in diverse human cancers. Am J Physiol Regul Integr Comp Physiol 297: R1154-R1161, 2009.

26. Hua H, Lu C, Li W, Meng J, Wang D, Plotnikoff NP, Wang E, and Shan F: Comparison of stimulating effect on subpopulations of lymphocytes in human peripheral blood by methionine enkephalin with IL-2 and IFN- $\gamma$. Hum Vaccin Immunother 8: 1082-1089, 2012. 
27. Wang DM, Wang GC, Yang J, Plotnikoff NP, Griffin N, Han YM Qi RQ, Gao XH and Shan FP: Inhibition of the growth of human melanoma cells by methionine enkephalin. Mol Med Rep 14: 5521-5527, 2016.

28. Xue M, Sun H, Cao Y, Wang G, Meng Y, Wang D and Hong Y: Mulberry leaf polysaccharides modulate murine bone-marrowderived dendritic cell maturation. Hum Vaccin Immunother 11: 946-950, 2015

29. Wang H, Czura CJ and Tracey KJ: Tumor necrosis factor. In: The Cytokine Handbook. 4th edition. Thomson AW and Lotze MT (eds). Academic Press, London, UK, pp837-860, 2003.

30. Motzer RJ, Hudes GR, Curti BD, McDermott DF, Escudier BJ, Negrier S, Duclos B, Moore L, O'Toole T, Boni JP, et al: Phase I/II trial of temsirolimus combined with interferon alfa for advanced renal cell carcinoma. J Clin Oncol 25: 3958-3964, 2007.

31. Shi VY, Tran K, Patel F, Leventhal J, Konia T, Fung MA, Wilken R, Garcia MS, Fitzmaurice SD, Joo J, et al: $100 \%$ Complete response rate in patients with cutaneous metastatic melanoma treated with intralesional interleukin (IL)-2, imiquimod, and topical retinoid combination therapy: Results of a case series. J Am Acad Dermatol 73: 645-654, 2015.
32. Leventhal JS, Odell ID, Imaeda S, Maverakis E and King BA: Treatment of melanoma in-transit metastases with combination intralesional interleukin-2, topical imiquimod, and tretinoin $0.1 \%$ cream. JAAD Case Rep 2: 114-116, 2016.

33. Fletcher JM, Lalor SJ, Sweeney CM, Tubridy N and Mills KH: $\mathrm{T}$ cells in multiple sclerosis and experimental autoimmune encephalomyelitis. Clin Exp Immunol 162: 1-11, 2010.

34. Kebir H, Kreymborg K, Ifergan I, Dodelet-Devillers A, Cayrol R, Bernard M, Giuliani F, Arbour N, Becher B and Prat A: Human TH17 lymphocytes promote blood-brain barrier disruption and central nervous system inflammation. Nat Med 13: 1173-1175, 2007.

35. Weir C, McNeill A, Hook S, Harvie M,La Flamme AC, Le Gros G and Bäckström BT: Critical role of preproenkephalin in experimental autoimmune encephalomyelitis. J Neuroimmunol 179: 18-25, 2006. 